\title{
Research Status and Progress of Genetic Mechanism of Abnormal Regular Sterane Distribution in Geological Bodies
}

\author{
Min Zhang \\ College of Resources and Environment, Yangtze University, Wuhan, China \\ Email: zmjpu@163.com
}

How to cite this paper: Zhang, M. (2018) Research Status and Progress of Genetic Mechanism of Abnormal Regular Sterane Distribution in Geological Bodies. Open Journal of Yangtze Gas and Oil, 3, 68-78. https://doi.org/10.4236/ojogas.2018.31006

Received: October 17, 2017

Accepted: January 28, 2018

Published: January 31, 2018

Copyright $\odot 2018$ by author and Scientific Research Publishing Inc. This work is licensed under the Creative Commons Attribution International License (CC BY 4.0).

http://creativecommons.org/licenses/by/4.0/

\section{c) (i) Open Access}

\begin{abstract}
Regular steranes occur ubiquitously in petroleum and hydrocarbon source rocks as an important composition part of biological markers. Abnormal regular sterane distribution occurring in hydrocarbon source rocks and crude oils has been widely reported in recent years, but their origin and genetic mechanism are unclear. This research gives an overview of regular steranes in sediments and crude oils, and states its possible development directions in the future. Based on systematic research on compound-specific carbon isotope compositions of regular steranes in sediments and crude oils using separation, enrichment, and purification of regular steranes in sediments and crude oils, combined with organic petrological, micropaleontological, and sedimentary geochemical characteristics of hydrocarbon source rocks with abnormal distribution of regular steranes, the occurrence, variation and main controlling factors of these compounds will be discussed, thus further uncovering their genetic mechanism and probing into their application on assessment of organic matter source, depositional environment and thermal maturity, as well as oil and source correlation. It not only enriches and improves the approaches and theories on biomarker study, but also will be the breakthrough for the new theory and application in oil and gas exploration.
\end{abstract}

\section{Keywords}

Abnormal Regular Sterane Distribution, Compound-Specific Carbon Isotope, Petroleum Geological Significance, Hydrocarbon Source Rocks

\section{Introduction}

As an important component of biological markers, steranes (cyclopentane per- 
hydro phenanthrene), particularly regular steranes, distribute in hydrocarbon source rocks and crude oils, referring to a class of tetracylic compound (also called steroid nucleu) with an alkyl side chain, in which an anglur methyl exists both in $\mathrm{A} / \mathrm{B}$ ring and $\mathrm{C} / \mathrm{D}$ rings. Although steranes are diverse in type, regular steranes are named according to their structures that contain a methyl at $\mathrm{C}-10$ and $\mathrm{C}-13$ position and five asymmetric carbon atoms (C-5, C-14, C-17, C-20 and $\mathrm{C}-24)$. Regular steranes widely distributed in the geosphere mainly consist of $\mathrm{C}_{27}$, $\mathrm{C}_{28}$, and $\mathrm{C}_{29} \alpha \alpha \alpha(20 \mathrm{~S}+20 \mathrm{R})$ and $\alpha \beta \beta(20 \mathrm{~S}+20 \mathrm{R})$.

$\mathrm{C}_{27}, \mathrm{C}_{28}$ and $\mathrm{C}_{29}$ steranes were first identified in the American green river and Pre-Cambrian shale by Burlingame (1965) [1]. Then, Eglinton and Calvin (1966) [2] and Eglinton and Murphy (1969) [3] further confirmed the existence of cholestane, ergostane and sitostane. After entering the 1970s, the species and quantities of biomarkers were not only quickly discovered and detected, but also their stereochemistry began to be studied. Kimble et al. (1974) [4] carried out a systematic research on the stereoconfiguration of steranes, and then gave their schematic diagrams and typical mass spectra, laying the foundation for the steroid geochemical attribute research. Based on the study of relative abundance and composition of $\mathrm{C}_{27}, \mathrm{C}_{28}$ and $\mathrm{C}_{29}$ sterols in various organisms and modern sediments in Mexico Bay, Huang and Meinshein (1979, 1981) [5] [6] suggested that algae was the predominant primary producer of $\mathrm{C}_{27}$-sterols, while $\mathrm{C}_{29}$-sterols were more typically associated with terrestrial land plants. On this basis, they proposed the distribution of $\mathrm{C}_{27}, \mathrm{C}_{28}$ and $\mathrm{C}_{29}$ sterols could be used to differentiate the organic matter source. Meanwhile, Mackenzie et al. (1980) [7] noted 20S/ $(20 \mathrm{~S}+20 \mathrm{R})$ and $\beta \beta /(\alpha \alpha+\beta \beta)$ values for the $\mathrm{C}_{29}$ steranes to describe the thermal maturity of hydrocarbon source rocks through the research on the evolution of steranes from Toarcian shales in Paris Basin, French. Seifert and Moldwan (1986) [8] considered that only the R configuration occurred in steroid precursors in living organisms, and this was gradually converted to a mixture of the $\mathrm{R}$ and $S$ configurations during burial maturation until $20 \mathrm{~S} /(20 \mathrm{~S}+20 \mathrm{R})$ values reaching the equilibrium around $0.52-0.55$. Furthermore, due to the curved and warped $\alpha \beta \beta(20 \mathrm{R}, 20 \mathrm{~S})$ configurations more resistant to thermal maturity than the flat-shaped $5 \alpha(\mathrm{H}), 14(\mathrm{H}), 17 \alpha(\mathrm{H}), 20 \mathrm{R}$ (also referred to $\alpha \alpha \alpha \mathrm{R}$ ) configurations, the $\alpha \alpha \alpha \mathrm{R}$ configuration was also converted gradually to $\alpha \beta \beta(20 \mathrm{R}, 20 \mathrm{~S})$ configuration during burial maturation until the equilibrium ratio for the $\alpha \alpha \alpha \mathrm{R}$, $\alpha \alpha \alpha \mathrm{S}, \alpha \beta \beta \mathrm{R}$ and $\alpha \beta \beta \mathrm{S}$ configuration reaching to 1:1:3:3 [9]. After that, the geochemical characteristics of normal regular sterane distributions have been widely discussed, with the emphasis on their applications on the assessment of organic matter source, sedimentary environment and thermal maturity as well as oil and source correlation. The molecular biology research shows that the steranes are formed by the diagenesis of sterols derived from the oxidation of squalene from exurkaryotes in aerobic conditions [10] [11] [12]. The fact that steranes are from the sterols in the eukaryotic cell membrane lipid has been confirmed at present [10] [13]. The predominant primary producers of $\mathrm{C}_{27}$-sterols are phytoplankton and crustaceans, while $\mathrm{C}_{28}$-sterols dominate the advantage in fungi and the ter- 
restrial plants are dominated by $\mathrm{C}_{29}$-sterols. That is, high abundance of $\mathrm{C}_{29}$ regular steranes indicates a significant higher-plant input, while the $\mathrm{C}_{27}$ regular steranes are more likely derived from phytoplankton [14] [15] [16] [17]. However, isomerization at $\mathrm{C}-14$ and $\mathrm{C}-17$ in the $\mathrm{C}_{29} 20 \mathrm{~S}$ and $20 \mathrm{R}$ regular steranes causes an increase in $\beta \beta /(\alpha \alpha+\beta \beta)$ from near-zero values to $\sim 0.7(0.67-0.71=$ equilibrium ) with increasing maturity. This ratio appears to be independent of source organic matter input and somewhat slower to reach equilibrium than $20 \mathrm{~S} /(20 \mathrm{~S}+$ 20R), thus making it effective at higher levels of maturity. Furthermore, other factors, such as organic facies diffenences, weathering and biodegradation, also have an effect on sterane isomerization ratios [16].

Meanwhile, the presence of abnormal regular sterane distributions in source rocks and crude oils has also attracted the attention of organic geochemists. Even though abnormal regular sterane distributions in hydrocarbon source rocks and crude oils have hitherto been documented in numerous literatures, their origin and genetic mechanism still remain a puzzle. Based on the previous literatures and researches, this paper systematically summarizes the researches status of abnormal regular sterane distributions to discuss the development directions of abnormal regular streane distributions in the future, which may provide some new information for a better understanding of origins and genetic mechanisms of regular steranes with abnormal distributions in the future. This is not only one of the most interesting scientific issues in organic geochemistry field, but also a breakthrough for the new theories and applications in oil and gas exploration.

\section{Research Status}

\subsection{Abnormally High Abundance of $\mathrm{C}_{29}$ Regular Steranes}

Grantham (1986) [18] discovered the unusual regular sterane distributions in the study on geochemical characteristics of ancient crude oils from Amanan. This kind of crude oil was dominated by $\mathrm{C}_{29}$ regular steranes, while its $\mathrm{C}_{27}$ regular sterane relative content was lower. Obviously, the predominance of $\mathrm{C}_{29}$ regular steranes in this kind of crude oils is not indicative of terrestrial organic matter input, because the terrestrial vascular plants begin to flourish in the Devonian. Henceforth, some scholars have also identified the abnormally high abundance of $\mathrm{C}_{29}$ regular steranes in the Proterozoic and Paleozoic marine source rocks and crude oils [19] [20]. Hua and Huang (1989) [19] noted that the superiority of $\mathrm{C}_{29}$ regular steranes existed in the Lower Paleozoic and Proterozoic source rocks from Northern China, which was attributed to the input of cyanobacteria. Some species of cyanobacteria, most commonly found in Lower Paleozoic with an advantage of $\mathrm{C}_{29}$ regular steranes, has been reported by Volkman (1986) [21]. Through the research on the geochemical characteristic of Cambrian-Ordovician source rocks in Tarim Basin, Chen et al. (2001) [20] found that the regular sterane distributions during the Cambrian-Lower Ordovician differed from that of the Middle-Upper Ordovician source rocks in Tarim Basin, 
and demonstrated that the former had an inverted "L" pattern distribution of $\mathrm{C}_{29}>\mathrm{C}_{28}>\mathrm{C}_{27}$, while the latter was characterized by a " $\mathrm{V}$ " pattern distribution of $\mathrm{C}_{29}>\mathrm{C}_{27}>\mathrm{C}_{28}$. They suggested that the variation in regular sterane distributions during the Cambrian-Lower Ordovician and the Middle-Upper Ordovician might illustrate that the organic chemical structure components obviously changed during the evolutionary process of organisms. It is interesting that, Zhang et al. (2001) [22] detected the abnormally high concentration of dinosteranes, 4-methylsteranes, 24-norcholestanes and $\mathrm{C}_{28}$ regular steranes according to the study on Cambrian and Sinian source rocks in Tarim Basin, indicating the inputs of dinoflagellates and diatoms probably originated in the Mesozoic period or earlier. It suggested that some of the phytoplankton, such as dinoflagellates and diatoms, may have more ancient species.

\subsection{Thermal Effect on Regular Sterane Distribution}

In fact, the relative abundance and distribution of $\mathrm{C}_{27}, \mathrm{C}_{28}$ and $\mathrm{C}_{29}$ regular steranes can also be affected by thermal maturation. The relative abundance of $\mathrm{C}_{29}$ regular steranes decreases with increasing thermal maturity, while the relative abundance of $\mathrm{C}_{27}$ regular steranes has an increasing trend with thermal maturity. The thermal stability of $\mathrm{C}_{29}$ and $\mathrm{C}_{28}$ regular steranes worse than $\mathrm{C}_{27}$ regular steranes can be responsible for that. Moldowan et al. (1992) [23] found that $C_{27}, C_{28}$ and $\mathrm{C}_{29}$ regular steranes displayed an inverted "L" type distribution dominated by $\mathrm{C}_{29}$ regular steranes in the hydrous pyrolysis experiment of immature Triassic source rocks. There was a pronounced shift towards the $\mathrm{C}_{27}$ and $\mathrm{C}_{28}$ regular steranes with increasing maturity until the $\mathrm{C}_{27}, \mathrm{C}_{28}$ and $\mathrm{C}_{29}$ regular steranes showing an asymmetric "V" type distribution. The increase in $\mathrm{C}_{27}$ regular steranes indicated the formation of secondary $\mathrm{C}_{27}$ steranes from the demethylation of $\mathrm{C}_{29}$ steranes. However, through the study on absolute concentrations of biomarkers in Carboniferous coals from western Pennsylvania and eastern Ohio, Dou et al. (1995) [24] found that the absolute amount of $\mathrm{C}_{29}$ regular sterane was initially high in coals of low maturity, but decreased rapidly in the $0.6 \%-1.0 \% R_{\mathrm{o}}$ range and then remained relatively constant at high maturities, while the absolute concentration of $\mathrm{C}_{27}$ was uniform through the entire maturity range, resulting in $\mathrm{C}_{29} / \mathrm{C}_{27}$ sterane ratios that essentially followed the trend of decreasing $\mathrm{C}_{29}$ steranes. Subsequently, Zhang et al. (2002) [25] discovered that the content of $\mathrm{C}_{27}$ regular steranes increased with increasing thermal maturity through the analysis of geochemical characteristics of the Jurassic and Triassic cores and coal samples of outcrops in Kuche Depression of Tarim Basin, especially at late mature stage. Sun and Duan (2011) [26] conducted a simulation experiment on peat and coal, which indicated that the relative content of $\mathrm{C}_{29}$ regular steranes increased with simulated temperature increase and then remained constant after simulated temperature up to $350^{\circ} \mathrm{C}$, while that of $\mathrm{C}_{27}$ and $\mathrm{C}_{28}$ regular steranes had an increasing trend through the entire maturity range. Nevertheless, it should be noted that according to Yang et al. (2017) [27], as shown in Figure 1, the $C_{27} / C_{29}$ 


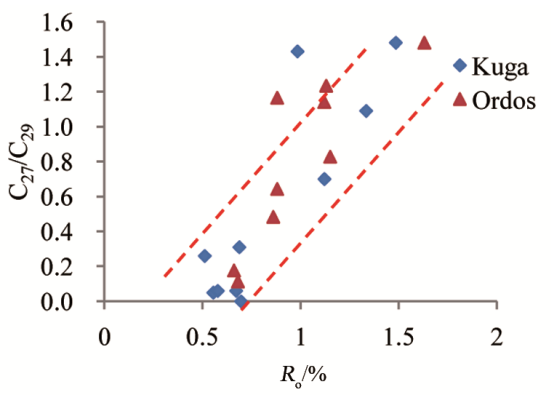

(a)

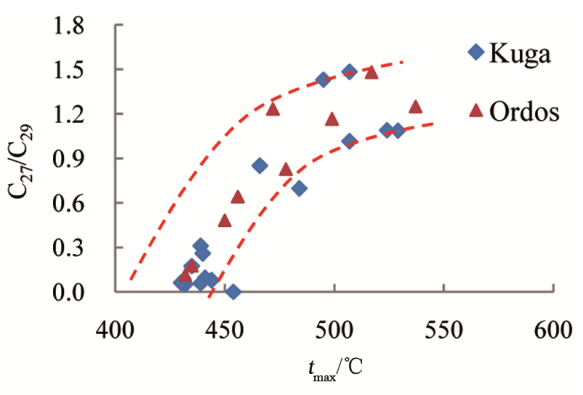

(b)

Figure 1. The plot of $\mathrm{C}_{27} / \mathrm{C}_{29}$ sterane vs. $R_{\mathrm{o}}$ and $t_{\max }$ of coal from Kuga sag and Ordos Basin (Yang et al., 2017).

sterane ratios in the colas from Kuga sag and Ordos Basin also changed significantly with thermal maturity on the research of the thermal effect on distributions of regular steranes, increasing with enhanced $R_{\mathrm{o}}$ values or $t_{\max }$ values. This phenomenon further illustrates that the thermal maturation has some connections with the distributions of regular steranes.

\subsection{Abnormally High Abundance of $\beta \beta$ Steranes}

Generally speaking, the isomerization degree of regular steranes is related to thermal maturity [8] [9] [16]. However, Ten Haven et al. (1986) [28] suggested early diagenetic formation of steranes in hypersaline environments. Abundant $\beta \beta$ steranes in these sediments could be due to reaction with sulfur. Rullkǒtter and Mariz (1988) [29] noted higher $\beta \beta /(\beta \beta+\alpha \alpha)$ and $20 S /(20 S+20 \mathrm{R})$ for extracts from hypersaline rocks. Peakman et al. (1989) [30] identified the series of (20R)- and $20 \mathrm{~S}-\Delta^{8(14)}$ and $\Delta^{14} 5 \alpha(\mathrm{H})$-sterenes in an immature marl from a hypersaline deposit (northern Apennines, Italy) by co-injection studies with authentic compounds. These alkenes co-occurred with $\Delta^{13(17)} 5 \alpha(\mathrm{H})$-spirosterenes and transient (20R)- and (20S)- $\Delta^{14} 5 \alpha(\mathrm{H}), 17 \beta(\mathrm{H})$-sterenes. They indicated that the unusually high degree of isomerisation may result from diagenetic reduction of $\Delta^{7}(14)$ and $\Delta^{8}(14), 5 \alpha(\mathrm{H})$-sterols via the $\Delta^{14} 5 \alpha(\mathrm{H}), 17 \beta(\mathrm{H})$-sterenes. This diagenetic pathway was supported by laboratory rearrangenment/hydrogenation experiments. And through the comparison of $(20 \mathrm{R}) /(20 \mathrm{~S})$ sterane values in different carbon number, $5 \alpha(\mathrm{H}), 14 \beta(\mathrm{H}), 17 \beta(\mathrm{H})$-steranes were confirmed to be actually related to $\Delta^{13(17)} 5 \alpha(\mathrm{H})$-spiral sterenes and $\Delta^{8}(14)$ and $\Delta^{14} 5 \alpha(\mathrm{H})$-sterenes rather than $5 \alpha(\mathrm{H}), 14 \alpha(\mathrm{H}), 17 \alpha(\mathrm{H})$-steranes. In addition, the regular steranes distributions with unusually high isomerization were detected in immature-low mature Paleogene source rocks of Bohai Bay Basin [31] [32], namely, the abundances of $5 \alpha(\mathrm{H}), 14 \beta(\mathrm{H}), 17 \beta(\mathrm{H})$-sterane configuration and $\alpha \alpha \alpha-20 \mathrm{~S}$ configuration were higher in these sediments. The crude oil from central region of Tarim Basin was divided into three types according to the unusual regular sterane distributions of crude oils. It should be noted that the distributions of steroids in three types of crude oils were similar to each other. They were all featured by the relative content of $\mathrm{C}_{27}$ regular steranes lower than that of $\mathrm{C}_{28}$ and $\mathrm{C}_{29}$ steranes and the relative abundance of $\mathrm{C}_{27}, \mathrm{C}_{28}$ and $\mathrm{C}_{29}-\beta \beta$ isomers higher than that of $\alpha \alpha$ 
isomers, but their origins were inconsistent. The first and third types of oils were mainly affected by thermal maturity and migrated fractionation, while the biodegradation beside thermal maturity and migrated fractionation had an effect on the second types of oil [33].

It is interesting that, the author recently carried out a study on the National Natural Science Foundation of China (Genesis mechanism of rearranged hopanes with high abundance in geological bodies and its significance in petroleum geology), finding that the regular sterane $\alpha \beta \beta$ isomers in the CarboniferousPermian coal measures of Ordos Basin and the Lower Cretaceous lacustrine source rocks and crude oils from the Lishu Fault Depression of Songliao Basin present the excellent correlations with rearranged hopanes including the $18 \alpha(\mathrm{H})$-neohopane series, $17 \alpha(\mathrm{H})$-diahopane series and early-eluting rearranged hopane series. This phenomenon appears to be not reported in previous literature.

\section{Development Trend}

Regarding the origins of abnormal regular steranes distributions, there is still no specific comment on it at present. One hypothesis is that the origin of $\mathrm{C}_{29}$ steranes in the Proterozoic and Paleozoic marine source rocks and crude oils is considered to be marine algae because the terrestrial vascular plants increase in population from the Devonian [34]. These marine algae are initially presumed to be cyanobacteria [21] [35], but later some scholars speculated that they may be macroscopic algae [36] [37]. However, the Proterozoic and Paleozoic $\mathrm{C}_{29}$ steranes are more likely to derive from the modern planktonic chlorella according to the data of micropaleontology, thermal simulation experiments and the stable carbon isotope of sterol in modern algae [38] [39] [40]. The formation of abnormally high abundance of $5 \alpha, 14 \beta(\mathrm{H}), 17 \beta(\mathrm{H}) 20 \mathrm{R}$ and $20 \mathrm{~S}$ steranes in immature-mature sediments and crude oils is more likely to be related to sedimentary environment rather than thermal effect [28] [30] [31] [32]. Ten Haven et al. (1986) [28] suggested that the reaction with sulfur can account for the presence of abundant $\beta \beta$ steranes in hypersaline environments, whereas Peakman et al. (1989) [30] proposed that the abnormally high degree of isomerisation may ascribe to diagenetic reduction of $\Delta^{7}(14)$ and $\Delta^{8}(14), 5 \alpha(\mathrm{H})$-sterols. Nevertheless, thermal simulation experiment showed that the bacterial action, which occurred in low-evolutionary source rocks of salt lacustrine facies during the early stage of sedimentation and diagenesis, was favorable for the conversion of $\alpha \alpha \alpha$ configuration to $\alpha \beta \beta$ configuration due to the reduction of activation energy of organic matters [41]. Furthermore, thermal maturity may contribute to abnormal regular sterane distributions [23] [24] [25] [26] [27]. Generally, the relative concentration of $\mathrm{C}_{27}$ regular steranes increases with the increasing maturity, whilst $\mathrm{C}_{29}$ regular sterane abundance shows a decreasing trend with maturity [23] [25] [26] [27]. In summary, multiple controlling factors on the distribution and genetic mechanism of abnormal regular steranes are still controversial and being inves- 
tigated.

Methods and techniques in previous literature and research, which are used in abnormal regular sterane distribution studies, include three aspects. First, according to the distributions of modern marine algae sterol and combination of modern biology, organic petrology and micropaleontology are used to reveal the organic matter source of regular steranes with unusual distributions [40]. Also, geochemical properties of unusual regular sterane distributions are investigated on the basis of studying the relative abundance and distribution of biology markers in source rock extracts and crude oils using GC-MS and GC-MS-MS analysis techniques [16] [21]. In addition, thermal simulation experiments were carried out to study thermal simulation products of mudstones and coals derived from different sedimentary environments, and then the researchers discussed the thermal effect on the isomerization degree of regular steranes [26] [42]. However, considering the abnormal distributions of the source, genetic mechanism and geochemical property of regular steranes, which are still under active investigation, it is urgent to exploit some new approaches for the assessment of the geochemical characteristics of hydrocarbon source rocks and crude oils.

With the increasing perfection of gas-chromatography-isotope ratio-mass spectrometry (GC-IRMS), especially the development of compound-specific carbon isotope, it therefore provides a powerful tool for the determination of compound-specific carbon isotope composition of biological makers [43] [44] [45] [46]. There are four main methods for separation, purification and enrichment of saturated hydrocarbon biomarkers, including silicalite, molecular sieve adsorption, urea treatment and sulfur urine complex. However, these methods are complicated and the repeatable analysis results are unsatisfactory. In order to meet the requirements for GC-IRMS analysis, Ryoshi et al. (2013) [47] used gel permeation chromatography (GPC) with a high performance liquid chromatography (HPLC) system for a more convenient and effective separation and enrichment for steroid and hopanoids of hydrocarbon source rocks and crude oils, which is an important milestone in the genesis and evolution studies of steroids. Different organism species have different carbon isotopes, which has been proved by the compound-specific carbon isotope composition of steroids derived from hydrocarbon source rocks and crude oils in geological bodies as well as in modern organisms [40] [47] [48]. However, there have hitherto been few reports on the distribution, variation, key controlling factors of compound-specific carbon isotope of abnormal regular steranes of hydrocarbon source rocks, crude oils originating from diverse sedimentary environment, genetic types and thermal maturity.

\section{Outlooks}

As mentioned above, comprehensive and systematic study on macroscopic composition, biomarker combination characteristic and compound-specific carbon isotope composition of hydrocarbon source rocks and crude oils con- 
taining abnormal regular sterane distributions can not only reveal the origin and genetic mechanism of unusual regular steranes, but also enrich and improve the methods and theories on biomarker study. In the future, we hope to roundly investigate the compound-specific carbon isotope compositions of regular steranes in sediments and crude oils using speration, enrichment, and purification of regular steranes in sediments and crude oils, intergrated with organic prteological, micropaleontological, and sedimentary geochemical characteristics of hydrocarbon source rocks with abnormal regular sterane distributions to discuss the occurrence, variation and main controlling factors of these compounds. This information may contribute to a better understanding of origins and genetic mechanisms of regular steranes with abnormal distributions and further exploit the new applications on the genesis of hydrocarbons, oil and source correlation, quantitative assessment of crude oil mixing degree and secondary alteration to expand the new research orientation in petroleum geology and organic geochemistry.

\section{Acknowledgements}

This research is financially supported by the National Natural Science Foundation of China (Grant No. 41772124).

\section{References}

[1] Burlinggame, A.L., Haug, P., Belsky, T. and Calvin, M. (1965) Occurrence of Biogenic Steranes and Pentacyclic Triterpanes in an Eocene Shale (52 Million Years) and in an Early Precambrian Shale (2.7 Billion Years): A Preliminary Report. Proceedings of the National Academy of Sciences of the United States of America, 54, 1406-1412. https://doi.org/10.1073/pnas.54.5.1406

[2] Eglinton, G. and Calvin, M. (1966) Chemical Fossils. Scientifical American, 216, 32-43. https://doi.org/10.1038/scientificamerican0167-32

[3] Eglinton, G. and Murphy, M.E. (1969) Organic Geochemistry: Methods and Results. Springer-Verlag, Berlin, 20-73. https://doi.org/10.1007/978-3-642-87734-6

[4] Kimbl, B.J., Maxwell, J.R., Philp, R.P. and Eglinton, G. (1974) Identification of Steranes and Triterpanes in Geolidid Extracts by High-Resolution Gas Chromatography and Mass Spectrometry. Chemical Geology, 14, 173-198. https://doi.org/10.1016/0009-2541(74)90127-2

[5] Huang, W.Y. and Meinshein, W.G. (1979) Sterols as Ecological Indicators. Geochimica et Cosmochimica Acta, 43, 739-745. https://doi.org/10.1016/0016-7037(79)90257-6

[6] Meinschein, W.G. and Huang, W.Y. (1981) Sterols, Stanols, Steranes, and the Origin of Natural Gas and Petroleum. In: Atkinson, G. and Zuckerman, J.L., Eds., Origin and Chemistry of Petroleum, Pergamon Press, 33-35. https://doi.org/10.1016/B978-0-08-026179-9.50006-2

[7] Mackenzie, A.S., Patience, R.L., Maxwell, J.R., Vandenbroucke, M. and Durand, B. (1980) Molecular Parameters of Maturation in a Toarcian Shales, Paris Basin, France-I. Changes in the Configuration of Acyclic Isoprenoid Alknes, Steranes, and Triterpanes. Geochimica et Cosmochimica Acta, 44, 1709-1721. https://doi.org/10.1016/0016-7037(80)90222-7 
[8] Seifert, W.K. and Moldowan, J.M. (1986) Use of Biological Markers in Petroleum Exploration. Mothods in Geochemistry and Geophysics, 24, 261-290.

[9] Peters, K.E. and Moldowan, J.M. (1993) The Biomarker Guide. Interpreting Molecular Fossils in Petroleum and Ancient Sediments. Prentice Hall, New Jersey.

[10] Volkman, J.K. (2005) Sterols and Other Triterpenoids: Source Specificity and Evolution of Biosynthetic Pathways. Organic Geochemistry, 36, 139-159. https://doi.org/10.1016/j.orggeochem.2004.06.013

[11] Dietrich, L.E., Tice, M.M. and Newman, D.K. (2006) The Co-Evolution of Life and Earth. Current Biology, 16, 395-400. https://doi.org/10.1016/j.cub.2006.05.017

[12] Summons, R.E., Bradley, A.S., Jahnke, L.L. and Waldbauer, J.R. (2006) Steroids, Triterpenoids and Molecular Oxygen. Philosophical Transactions of the Royal Society B: Biological Sciences, 361, 951-968. https://doi.org/10.1098/rstb.2006.1837

[13] Volkman, J.K. (2003) Sterols in Microorganisms. Applied Microbiology and Biotechnology, 60, 495-506. https://doi.org/10.1007/s00253-002-1172-8

[14] Tissot, B.P. and Welte, D.H. (1978) Petroleum Formation and Occurrence. Springer-Verlag, Berlin. https://doi.org/10.1007/978-3-642-96446-6

[15] Philp, R.P. (1985) Fossi Fuel Biomarkers. Elsevier Science Publishing Company Inc., New York, 1-294.

[16] Peters, K.E., Walters, C.C. and Moldowan, J.M. (2005) The Biomarker Guide, Biomarkers and Isotopes in Petroleum Exploration and Earth History. 2nd Edition, Cambridge University Press, New York.

[17] Zeng, X.Z., Liang, D.G., Wang, Z.R., Zhang, Z.C., Liu, S.Z. and Ma, S.P. (1986) Biomarkers of Terrestrial Oil and Source Rock of China. Gansu Science Technology Press, Lanzhou, 1-310.

[18] Grantham, P.J. (1986) The Occurrence of Unusual $\mathrm{C}_{27}$ and $\mathrm{C}_{29}$ Sterane Predominances in Two Types of Oman Crude Oil. Organic Geochemistry, 9, 1-10. https://doi.org/10.1016/0146-6380(86)90077-X

[19] Hua, A.X. and Huang, D.F. (1988) Hydrocarbon Generation and Biological Marker Characteristics in Mid-Upper Proterozoic in North China. Lanzhou Institute of Geology of Development Laboratory of Gas Geochemistry Research Report, Lanzhou, $10-42$.

[20] Chen, S.J., Shen, Z.G., Fu, X.W., Wang, X.L., Huang, D.F. and Li, X.D. (2001) Biological Markers Application in Stratigraphic Division and Correlatio-Take Lower Paleozoic Strata in Tarim Basin as Example. Journal of Stratigraphy, 25, 288-291.

[21] Volkman, J.K. (1986) A Review of Sterol Markers f or Marine and Terrigenous Organic Matter. Organic Geochemistry, 9, 83-99. https://doi.org/10.1016/0146-6380(86)90089-6

[22] Zhang, S.C., Moldwan, J.M., Li, M.W., Bian, L.Z., Zhang, B.M., Wang, F.Y., et al. (2001) The Abnormal Distribution of the Molecular Fossils in the Pre-Cambrian and Cambrian: Its Biological Significance. Science China (D), 31, 299-304.

[23] Moldowan, J.M., Sundararaman, P., Salvatori, T., Alajbeg, A., Gjukic, B., Lee, C.Y. and Demaison, G.J. (1992) Source Correlation and Maturity Assessment of Select Oils and Rocks from the Central Adriativ Basin (Italy and Yugoslavia). In: Moldowan, J.M., Albrecht, P. and Philp, R.P., Eds., Biological Markers in Sediments and Petroleum, Prentice Hall, Englewood Cliffs, 370-401.

[24] Dzou, L.I.P., Noble, R.A. and Senftle, J.T. (1995) Maturation Effects on Absolute Biomarker Concentration in a Suite of Coals and Associated Vitrinite Concentrates. Organic Geochemistry, 23, 681-697. https://doi.org/10.1016/0146-6380(95)00035-D 
[25] Zhang, J., Chen, J.P., Zhang, C.M. and Wang, P.R. (2002) Relationship between Biomarker Composition and Maturity in Coal of Kuche Depression. Journal of Jianghan Petroleum Institute, 24, 27-29.

[26] Sun, T. and Duan, Y. (2011) Geochemical Characyeristics of Steranes of Coal Generated Hydrocarbons: A Case of High Temperature and Fined Simulated Experiment. Natural Gas Geoscience, 22, 1082-1087.

[27] Yang, Y.F., Zhang, M., Chen, J.L. and Chen, X.H. (2017) Thermal Effect on the Distribution of Regular Sterane and Geoligical Significance. Open Journal of Yangtze Gas and Oil, 4, 249-259. https://doi.org/10.4236/ojogas.2017.24020

[28] Ten Haven, H.L., de Leeuw, J.W., Peakman, T.M. and Maxwell, J.R. (1986) Anomalies in Steroid and Hopanoid Maturity Indices. Geochimica et Cosmochimica Acta, 50, 853-855. https://doi.org/10.1016/0016-7037(86)90361-3

[29] Rullkotter, J. and Marzi, R. (1988) Natural and Artificial Maturation of Biological Markers in a Toarcian Shale from Northern Germany. Organic Geochemistry, 13, 639-645. https://doi.org/10.1016/0146-6380(88)90084-8

[30] Peakman, T.M., Ten Haven, H.L., Rechka, J.R., de Leeuw, J.W. and Maxwell, J.R. (1989) Occurrence of (20R)-and(20S)- $\Delta^{8(14)}$ and $\Delta^{14} 5 \alpha(\mathrm{H})$-sterenes and the Origin of $5 \alpha(\mathrm{H}), 14 \beta(\mathrm{H}), 17 \beta(\mathrm{H})$-steranes in Animmature Sediment. Geochimica et Cosmochimica Acta, 53, 2001-2009. https://doi.org/10.1016/0016-7037(89)90320-7

[31] Zhang, W.L., Qin, J.Z. and Tian, L. (2000) A Study on the Origin of High Maturity of Steranes and the Generation of Immature Oil from Paleogene in Jinxian Sag. Petroleum Exploration and Development, 27, 27-31.

[32] Li, S.M., Pang, X.Q. and Jin, Z.J. (2002) Distribution and Significance of Steriods in Bamianhe Oilfield, East China. Earth Science-Journal of China University of Geosciences, 27, 711-717.

[33] Qin, L.M., Zhang, Z.H., Yang, Y.C., Li, W., Liu, H.J. and Mei, L. (2008) Abnormal Distribution and Its Origin of Steriods in the Block of Central Jungger Basin. Journal of Earth Sciences and Environment, 30, 373-379.

[34] Gray, J. and Boucota, J. (1978) The Advent of Land Plant Life. Geology, 6, 489-492. https://doi.org/10.1130/0091-7613(1978)6<489:TAOLPL>2.0.CO;2

[35] Grantham, P.J. and Wakefiled, I.I. (1998) Variations in the Sterane Carbon Number Distributions of Marine Source Rock Derived Crude Oils through Geological Time. Organic Geochemistry, 12, 61-73.

[36] Wang, F.Y., Bian, L.Z., Zhang, S.C., Zhang, B.M. and Liang, D.G. (2001) Two Groups of Organic Maceral in the Ordovician Source Rocks, Tarim Basin. Science China, 31, 96-102.

[37] Bian, L.Z., Zhang, S.C., Liang, D.G., Zhang, B.M., Wang, D.R. and Yin, L.M. (2003) Fruit-Like Fossils of Ancient Seaweeds from Late Ordovician, Central Area of the Tarim Basin and the Charaters of Bioprecursors of Tazhong Oil and Gas Field. Acta Micropalaeontologica Sinica, 20, 89-96.

[38] Berkaloff, C., Casadevall, E. and Largeau, C. (1983) The Resistant Polymer of the Cell Walls of the Hydrocarbon-Rich Algae Botryococcus braunii. Photochemistry, 22, 389-397. https://doi.org/10.1016/0031-9422(83)83010-6

[39] Moldowan, J.M., Dahl, J. and Jacobson, S.R. (1996) Chemo Stratigraphic Reconstruction of Biofacies: Molecular Evidence Lingking Cyst-Forming Dinoflagellates with Pre-Triassic an Eestoes. Geology, 24, 159-162. https://doi.org/10.1130/0091-7613(1996)024<0159:CROBME>2.3.CO;2

[40] Meng, F.W., Zhou, C.M. Yan, K. and Yuan, X.L. (2006) Biological Origin of Early 
Palaeozoic and Pre-Cambrian Hydrocarbon Source Rocks Based on $\mathrm{C}_{27} / \mathrm{C}_{29}$ Sterane Ratio and Organic Carbon Isotope. Acta Micropalaeontologica Sinica, 23, 51-56.

[41] Meng, Q.X., Sun, M.Z., F, X., Wang, Z.D., Wang, G.C. and Xu, Y. (2007) Hydrocarbon Generation Mechanism and Evolution Characteristics of Biomarkers on Low-Evolutionary Source Rocks of the Salt Lacustrine Facies. Acta Sedimentologica Sinica, 25, 800-807.

[42] Liang, M.L., Wang, Z.D. and Zheng, J.J. (2015) Geochemical Characteristics of Steranes and Tepanes in Lacustrine Quality Source Rocks by Thermal Simulation Experiment. Bulletin of Mineralogy, Petrology and Geochemistry, 34, 968-973.

[43] Hayes, J.M., Freeman, K.H., Popp, B.N. and Hoham, C.H. (1990) Compound Specific Isotope Analyses, a Novel Tool for Reconstruction of Ancient Biogeochemical Processes. Advances in Organic Geochemistry, 16, 1115-1128. https://doi.org/10.1016/0146-6380(90)90147-R

[44] Dong, A.Z., Zhang, L.Y., Huang, D.F., Wang, T.K. and Zhang, D.J. (1996) The Method of Carbon Isotope Measurement of Individual Compounds in Saturated Hydrocarbon. Petroleum Exploration and Development, 23, 98-102.

[45] Xiong, Y.Q., Geng, A.S. and Liu, D.G. (1998) Stable Carbon Isotopic Compositions of Compound Specific Terpanoils for Heavy Oils in Kelamayi Oilfield, NW China. Chinese Bulletin of Sciences, 43, 1312-1315.

[46] Wang, H.T., Wei, C.Y., Zhang, S.C., Zhang, D.J. and Yang, A.D. (2010) The Study on Biomarkers Separation and Its Csia by MOY Molecular Sieve. Petroleum Geology \& Experiment, 32, 513-516.

[47] Ishiwatari, R., Ishiwatari, M., Kisamori, S. and OKui, A. (2013) Selective Enrichment of Steroid and Triterpenoid Hydrocarbons from Crude Oil using Gel Permeation Chromatography for Stable Carbon Isotope Analysis. Organic Geochemistry, 61, 27-33. https://doi.org/10.1016/j.orggeochem.2013.05.002

[48] Hu, G.Y., Ran, Q.G., Wang, T.G. and Zhong, N.N. (1997) Preliminary Study on Saturate Components Characteristics and Its Origin of Fuling Formation Immature Source Rock in Jinhu Sag. Acta Sedimentologica Sinica, 15, 138-141. 